\title{
Brainier Babies?
}

Duane Helleloid, University of North Dakota, USA

\begin{abstract}
The Campaign for a Commercial-Free Childhood (CCFC) had been arguing for years that videos targeted at small children had no educational or brain-development value, and were potentially harmful to child development. Over the years, Baby Einstein, the market leader in videos targeted at children under three, had removed any educational references from its advertising, packaging, and websites, and had also removed most testimonials from its website. In September 2009, Baby Einstein offered a refund to anyone who had purchased its products in the past five years, and indicated that the move reiterated its strong commitment to consumers and its products. This move clearly put the ball back in the CCFC's court, as it had to decide if, and how, it might proceed in its efforts against videos targeted at small children.
\end{abstract}

Keywords: Baby Einstein, CCFC, educational videos, child development

\section{INTRODUCTION}

n September 2009, The Baby Einstein Company announced that it would offer a refund to anyone who purchased "Baby Einstein" DVDs over the previous 5 years $[3,6]$. This announcement followed years of escalating concerns over the marketing of products that were viewed to be educational or contributing to brain development in infants and toddlers. Susan McLain, General Manager of The Baby Einstein Company, indicated that this announcement simply meant that the company had decided to extend the time period of its existing refund policy, and that this move was not motivated by pressure from activist groups like the Campaign for a Commercial-Free Childhood (CCFC). Baby Einstein maintained that videos can be a valuable interactive tool to promote parents' interactions with their children, and that by extending the refund period to five years, it showed their strong support for the product [4].

For Susan Linn, CCFC Director, this move by Baby Einstein created a new opportunity, and challenge. Baby Einstein was formally standing behind its product, and indicating that it believed the Baby Einstein videos were something parents would continue to buy and value. After years of challenging Baby Einstein's position that videos should made and marketed at all to infants and toddlers, should CCFC refocus its efforts on other causes, or claim victory for forcing Baby Einstein to implement such an unusual refund policy, or pursue some other approach to try and force Baby Einstein to stop making and marketing videos designed for infants and toddlers. Although the CCFC's tactics had helped force some change in the marketing and labeling of the Baby Einstein videos, the organization had been unsuccessful in achieving its goal of eliminating such videos from the market [7].

\section{THE CAMPAIGN FOR A COMMERCIAL-FREE CHILDHOOD}

The Campaign for a Commercial-Free Childhood (CCFC) was formed in 2004, the new name for the group previously called Stop Commercial Exploitation of Children. Led by Susan Linn, CCFC's goal was to limit marketing directed to children. "CFCC works for the rights of children to grow up - and the freedom for parents to raise them - without being undermined by commercial interests." The CCFC had brought attention to a number of corporations that targeted advertising to children, and specifically those that did so at schools or other places where it believed children should be able to enjoy life and learn without being exposed to commercials. The Scholastic Book Company, for example, had decided to limit some of the products it sold at school book fairs, under pressure from parent groups and the CCFC. The CCFC also collaborated with the Center for Science in the Public Interest to sue Kellogg Corporation over the marketing of breakfast cereals at schools [2,5]. 
One of CCFC's most prominent causes was its campaign against Baby Einstein and Brainy Baby over the sale of videos that targeted children under two years of age. Over time, these companies had dropped any references to "educational" or "stimulating development" from the marketing and packaging of these videos, and had changed some of the testimonials on the packaging and websites to eliminate any claims about benefits to children from watching the videos. In 2006, CCFC filed a complaint with the Federal Trade Commission (FTC) claiming that the company's websites and packaging contained claims that were not supported by scientific research, although after investigating the complaint and receiving assurances that certain changes would be made, the FTC chose to take no action against the firms. In 2008, the CCFC retained attorneys to develop a class action suit against Baby Einstein, that among other things, would require that Baby Einstein provide refunds to any customers that requested them. To this point, a class action suit had not been filed, and it was unclear if Baby Einstein's revised extended refund policy would essentially undermine the need for a lawsuit $[8,9,10]$.

\section{THE BABY EINSTEIN COMPANY}

The Baby Einstein Company was founded in 1997 by Julie Aigner-Clark. The first movies were shot in her home, using toys, her own children, the household cat, hand puppets, and musical background music. After initial success, more movies were shot, and she sold the company to Disney in 2001 for an estimated $\$ 20$ million. The company continues to pay royalties to the estate of Albert Einstein for use of his name. Under Disney, the company expanded it product offering to include Baby da Vinci, Baby Monet Discovering the Seasons, Baby Bach, and Little van Gough, among other titles. The Baby Einstein Company states that its goal is to help create "interactive experiences" between parents and their children and that "its videos and other products are just one of many tools and activities parents can use throughout the day to interact and bond with their child" [1,3].

In recognition of the concerns expressed regarding videos, the company's website now clearly states "Baby Einstein products are not designed to make babies smarter. Rather, Baby Einstein products are specifically designed to engage babies and provide parents with tools to help expose their little ones to the world around them in playful and engaging ways - inspiring a baby's natural curiosity." Given that in some homes a television may be on almost constantly, the company believes that it is important that the content on the television be age appropriate [1].

\section{THE SCIENTIFIC RESEARCH}

In the early 1990s, several studies showed that listening to certain types of music (typically classical) helped adults perform certain tasks better than if there was no music, or disruptive sounds. Less scientific studies indicated that small children (and house pets) responded positively to certain music, and became agitated when exposed to more modern music. This helped create the environment where multiple individuals and firms began selling and marketing educational music and video products aimed at small children. In some cases claims were made that these products would make a baby smarter, or help promote brain development, or increase a child's ability to recognize colors and shapes. Other companies simply marketed videos as family entertainment [10].

In 2007, researchers from the University of Washington published a study in the Journal of Pediatrics that showed that exposure to television and videos retarded infants' language development. They found that for every hour per day spent watching baby videos and DVDs, infants understood an average of six to eight fewer words than infants who did not watch them at all. The general conclusion of the research was that children's development is best promoted by having bablies physically play and talk with adults, not by watching a screen [11]. The study did not, however, explicitly separate the effects from different types of screen time (e.g., Sesame Street, Baby Einstein, or cartoons). This left open the question whether it was accurate to lump all types of children's videos together when reaching the conclusion. Subsequently, the American Academy of Pediatrics recommended no screen time at all for children under two years of age [3,9].

\section{THE NEXT MOVE FOR THE CCFC}

The CFCC had long been pressuring Baby Einstein (and companies that published similar videos) to remove any reference to "educational" or "stimulating development" from the advertising and packaging of their DVDs, and had largely succeeded in those goals [7]. Its efforts to enlist the FTC in its efforts to remove such videos 
from the market altogether, however, had not succeeded, and it faced challenges in launching a class action suit against the company. With Baby Einstein announcing a five year refund, the benefits of a class action suit for consumers would be minimal. The CCFC could continue to press for the elimination of videos targeted at children under two, and perhaps use Baby Einstein's decision to offer the extended refund as a opportunity to claim its pressure tactics had succeeded. Alternatively, it could decide to focus its efforts on other situations where children were the target of advertising, including new websites that were a mixture of games, social networking, and subtle advertising to kids. Or perhaps there were other approaches it could take to educate parents on the appropriate use of videos with small children.

\section{DISCUSSION QUESTIONS}

1. Has the CCFC's campaign against Baby Einstein succeeded in achieving the organization's goals?

2. Has The Baby Einstein Company effectively managed the controversy over videos targeted at small children?

3. What moves should the CCFC consider next? What are the advantages and disadvantages of each?

4. What should the CCFC do next? Why?

5. What should Baby Einstein do next? Why?

\section{AUTHOR INFORMATION}

Duane Helleloid is Chair of the Management Department at the University of North Dakota. He teaches primarily strategic management, but has also taught leadership, ethics, international business, technology management, principles of management, and other courses UND, the University of Maryland, Towson University, the University of Connecticut, the Norwegian School of Management, the Stockholm School of Economics, and the University of Shanghai for Science and Technology.

\section{REFERENCES}

1. About Baby Einstein. (Accessed online at: http://www.babyeinstein.com/en/our_story/about_us/)

2. About CCFC. (Accessed online at: http://www.commercialexploitation.org/aboutus.htm)

3. Baby Einstein, Wikipedia (Accessed online at: http://en.wikipedia.org/wiki/Baby einstein)

4. Baby Einstein Sets the Record Straight On Refund (Accessed online at: http://www.babyeinstein.com/Refund/)

5. $\quad$ CCFC: Highlights and History (Accessed online at: http://www.commercialexploitation.org/about/history.htm)

6. Lewin, Tamar 2009. No Einstein in Your Crib? Get a Refund. New York Times, October 24, 2009. (Accessed online at: http://www.nytimes.com/2009/10/24/education/24baby.html)

7. CCFC Urges Baby Einstein to Come Clean with Parents: Advocates Document Years of Educational Claims. (Accessed online at: http://www.commercialexploitation.org/pressreleases/babyeinsteinurgedtocomeclean.html)

8. Interlandi, Jeneen 2007. Turn It Off, Baby. Newsweek, August 27, 2007. Volume 150, Issue 8/9, p. 14.

9. Mayer, Caroline 2006. Group Sues Video Firms on Tot-Learning Claims. Washington Post, May 2, 2006, page D03. (Accessed online at: http://www.washingtonpost.com/wpdyn/content/article/2006/05/01/AR2006050101372.html)

10. Quart, Alissa 2006. Extreme Parenting: Does the baby genius edutainment complex enrich your child's mind - or stifle it? The Atlantic Monthly, July/August 2006. (Accessed online at: http://www.theatlantic.com/doc/200607/parenting)

11. Schwarz, Joel 2007. Baby DVDs, videos may hinder, not help, infants' language development. August 7, 2007. (Accessed online at: http://uwnews.washington.edu/ni/article.asp?articleID=35898) 


\section{NOTES}

